Reviu Akuntansi dan Bisnis Indonesia, Vol. 2 No. 2, Hlm: 171-185, Desember 2018

Website: http://journal.umy.ac.id/index.php/rab

\title{
Pengaruh Flypaper Effect, Pendapatan Asli Daerah (PAD) dan Produk Domestik Regional Bruto (PDRB) Terhadap Belanja Daerah (Studi Empiris pada Provinsi di Indonesia Tahun 2014-2016)
}

\author{
Woro Tiyas Pradipta; Bambang Jatmiko \\ Program Studi Akuntansi Univeritas Muhammadiyah Yogyakarta.
}

I N F O A R T I K E L

\section{Kata Kunci:}

Flypaper Effect, Dana Alokasi Umum (DAU), Dana Alokasi Khusus (DAK), Dana Bagi Hasil (DBH), Pendapatan Asli Daerah (PAD), Produk Domestik Regional Bruto (PDRB), Belanja Daerah.

Jenis Artikel:

Penelitian Empiris

Correspondence:

bambang_jatmiko65@yahoo.com

\author{
A B S T R A K
}

Penelitian ini bertujuan untuk mengetahui pengaruh Dana Alokasi Umum (DAU), Dana Alokasi Khusus (DAK), Pendapatan Bagi Hasil (DBH), Pendapatan Daerah (PAD), Produk Domestik Regional Bruto (PDRB) dan efek flypaper terhadap pengeluaran lokal. Metode yang digunakan dalam penelitian ini adalah metode deskriptif yang bertujuan untuk membuat deskripsi fakta yang sistematis, faktual, dan akurat. Penelitian ini bersifat kuantitatif dan sampelnya adalah 32 Provinsi di Indonesia. Metode analisis yang digunakan dalam penelitian ini adalah analisis regresi berganda dengan perangkat lunak Solusi Produk dan Layanan Statistik (SPSS). Hasil penelitian ini menunjukkan bahwa Dana Alokasi Khusus (DAK), Pendapatan Bagi Hasil (DBH), Pendapatan Daerah (PAD) berpengaruh positif terhadap pengeluaran daerah. Tetapi DAU dan PDRB tidak berpengaruh pada pengeluaran lokal. Pengaruh PAD terhadap pengeluaran lokal lebih besar dari pada pengaruh DAU, DAK, dan DBH secara simultan terhadap pengeluaran lokal, sehingga tidak ada fenomena efek flypaper di Provinsi Indonesia pada periode 2014-2016. Ini menunjukkan bahwa Ini menunjukkan bahwa pemerintah provinsi mandiri dalam keuangannya dengan tidak bergantung pada pemerintah pusat.

(C) 2019 RAB. Published by Universitas Muhammadiyah Yogyakarta

\section{PENDAHULUAN}

Pelaksanaan otonomi daerah sejak tahun 2001 sebagai wujud penerapan desentralisasi ditandai dengan diterapkannya Undang-Undang Nomor 22 Tahun 1999 tentang Pemerintah Daerah dan Undang-Undang Nomor 25 Tahun 1999 tentang Otonomi Daerah yang kemudian direvisi dalam Undang-Undang Nomor 32 Tahun 2004 dan Undang-Undang Nomor 33 Tahun 2004. Hal tersebut berdampak pada terbukanya peluang bagi pemerintah daerah untuk mengembangkan segala bentuk potensi daerahnya (endowment factor). Desentralisasi fiskal memberikan Pemerintah Daerah kewenangan untuk mengurus dan mengatur urusan rumah tangganya, sehingga mengharuskan pemerintah untuk mengelola secara optimal seluruh pendapatan daerahnya. Hal itu bertujuan untuk memenuhi kebutuhan belanja daerah yang akan digunakan untuk meningkatkan pelayanan publik, meningkatkan pembangunan daerah, serta memajukan perekonomian daerah untuk meningkatkan kesejahteraan masyarakatnya, baik dari segi sosial maupun ekonomi sebagai wujud pelaksanaan desentralisasi. 
Menurut UU No 33 Tahun 2004, pendapatan daerah bersumber dari Pendapatan Asli Daerah (PAD), Dana Perimbangan yang terdiri dari Dana Alokasi Umum (DAU), Dana Alokasi Khusus (DAK), dan Dana Bagi Hasil (DBH), dan Lain-lain Pendapatan. Pada prinsipnya desentralisasi fiskal mengharapkan kurangnya ketergantungan pemerintah daerah kepada pemerintah pusat, agar tercapainya daerah mandiri sesuai dengan tujuan otonomi daerah (Hasan dan Permana, 2012). Halim (2007) menyatakan bahwa untuk meminimalkan ketergantungan daerah terhadap pusat berkurang, maka Pendapatan Asli Daerah (PAD) harus menjadi sumber keuangan terbesar yang didukung oleh kebijakan perimbangan pusat dan daerah. Pada umumnya, alokasi transfer pada negara-negara yang sedang berkembang lebih didasarkan pada aspek belanja dan kurang memperhatikan kemampuannya dalam pengumpulan pajak lokal (Naganathan dan Sivagnanam dalam Nurdini.,dkk, 2014). Hal tersebut berdampak pada pemerintah daerah yang menuntut transfer lebih besar dari tahun ke tahun kepada pemerintah pusat (Shah dalam Nurdini.,dkk, 2014). Adanya suatu kondisi dimana respon yang diberikan oleh Pemerintah daerah terhadap dana perimbangan untuk membiayai kebutuhan belanja lebih besar daripada respon terhadap penggunaan PAD disebut dengan flypaper effect.

Flypaper effect memberi implikasi yang lebih bahwa adanya transfer akan memberikan dampak berupa peningkatan belanja daerah yang lebih besar daripada penerimaan transfer itu sendiri (Turnbull dalam Nurdini.,dkk 2014). Hal tersebut dapat dibuktikan dari Trend APBD tahun 2012-2016 secara nasional yang digambarkan dalam Gambar 1.

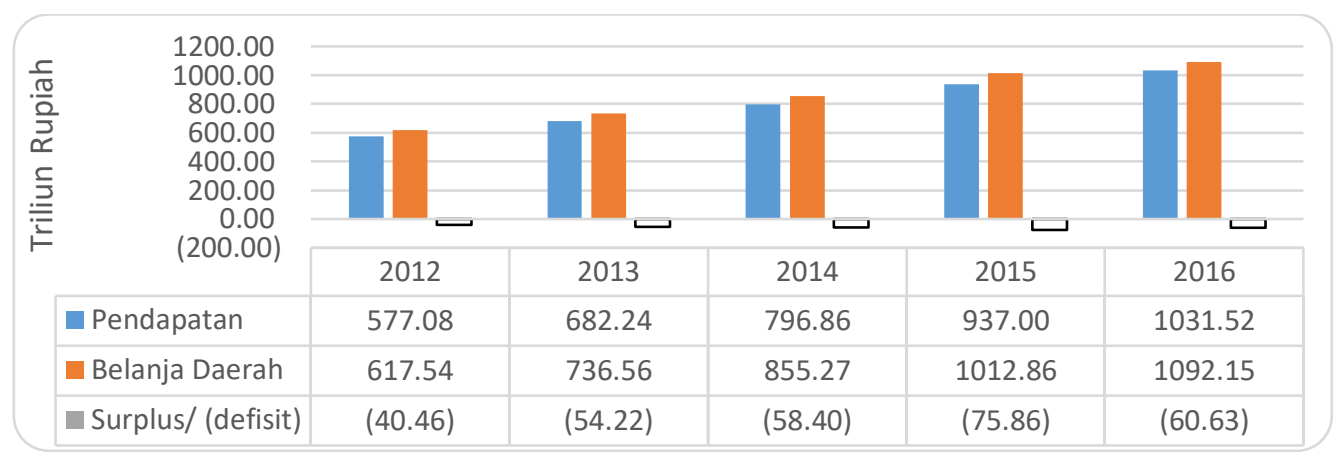

Gambar 1 Trend APBD Tahun 2012-2016 (dalam triliun rupiah) Sumber: Data APBD Direktorat Jendral Keuangan Daerah (diolah), 2017

Berdasarkan gambar diatas dapat diketahui bahwa dari tahun 2012-2016 pendapatan daerah terus mengalami peningkatan rata-rata sebesar $16 \%$ setiap tahunnya. Dïringi dengan peningkatan ratarata bekanja daerah sebesar $15,41 \%$ setiap tahunnya. Sehingga dapat dikatakan bahwa meningkatnya pendapatan daerah diikuti oleh pengeluaran belanja daerah. Sementara pendapatan daerah yang terdiri dari PAD, Dana Perimbangan (DAU, DAK, dan DBH), dan Lain-lain Pendapatan yang sah dapat dilihat kompisisinya pada Gambar dibawah ini:

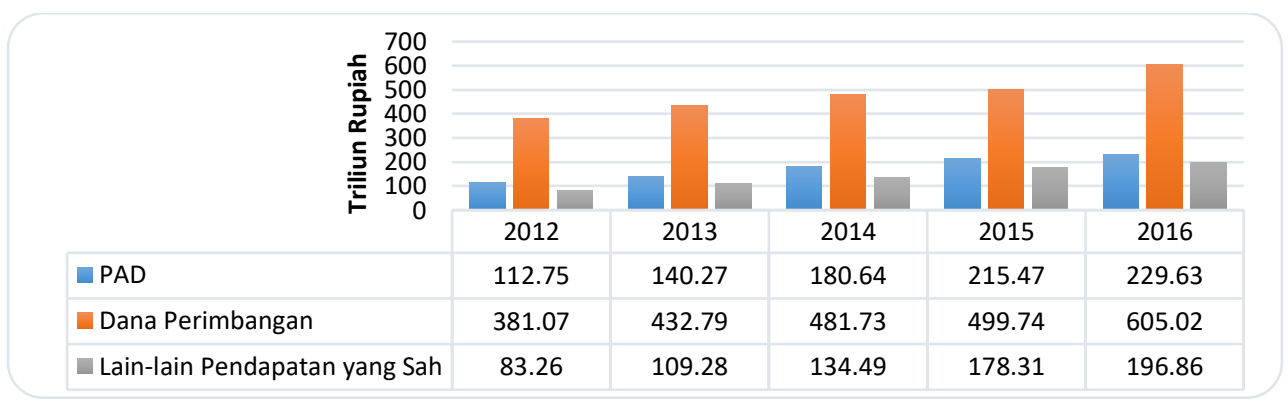

Gambar 2. Trend Komposisi Pendapatan Daerah Tahun 2012-2016 (dalam triliun rupiah) Sumber: Data APBD Direktorat Jendral Keuangan Daerah (diolah), 2017 
Pada gambar diatas PAD mengalami peningkatan rata-rata sebesar 19,76\% setiap tahunnya. Sementara rata-rata peningkatan Dana Perimbangan adalah sebesar $12,42 \%$ setiap tahunnya. Meskipun laju peningkatan dana perimbangan lebih kecil dibanding PAD, porsi dana perimbangan lebih dominan setiap tahunnya.

DirjenPerimbangan Keuangan Kemenkeu menyatakan bahwa meskipun kapasitas fiskalnya naik, persentasenya (keuangan daerah) masih sekitar 20\% dari total Anggaran Pendapatan Belanja Daerah (APBD) seluruh Indonesia. Kemudian pajak daerah dan retribusi hanya sekitar seperlima dari total kapasitas itu. Artinya, ketergantungan terhadap dana transfer masih tinggi sekitar 80\% (Bisnis Indonesia).

Selain menggunakan variabel PAD dan Dana Perimbangan (DAU, DAK dan DBH) yang mengacu pada penelitian Nurdini., dkk (2014) mengenai analisis flypaper effect pada DAU, DAK, DBH, dan PAD terhadap belanja daerah kabupaten/kota di Jawa Barat, peneliti menggunakan satu variabel tambahan yaitu Produk Domestik Regional Bruto (PDRB) yang mencerminkan pertumbuhan ekonomi di suatu daerah, apabila pertumbuhan ekonomi meningkat maka pendapatan yang diterima akan ikut meningkat yang berarti pengalokasian belanja daerah akan lebih besar. Variabel PDRB mengacu pada penelitian Iskandar (2012) mengenai flypaper effect pada unconditional grant. Maka peneliti tertarik untuk menyusun penelitian dengan judul "Pengaruh Flypaper Effect Produk Domestik Regional Bruto (PDRB) terhadap Belanja Daerah (Studi Empiris pada Provinsi di Indonesia tahun 2014-2016)”.

\section{TINJAUAN LITERATUR DAN PERUMUSAN HIPOTESIS}

\section{Teori Stewardship}

Donaldson dan Davis dalam Raharjo (2010) menjelaskan bahwa Teori Stewardship menggambarkan mengenai suatu situasi dimana manajer tidak termotivasi oleh tujan individu, melainkan termotivasi oleh sasaran atau tujuan yang berhubungan dengan kepentingan organisasi. Berdasarkan penjelasan tersebut, teori ini menggambarkan mengenai hubungan yang kuat antara kepuasan dan kesuksesan organisasi dalam mencapai tujuan atau sasarannya. Organisasi sektor publik memiliki tujuan untuk memberikan pelayanan kepada publik (masyarakat) dan dapat dipertanggungjawabkan kepada publik. Sehingga, teori stewardship dapat diterapkan dalam model khusus organisasi sektor publik

\section{Teori Perkembangan Pengeluaran Pemerintah (Peacock dan Wisman)}

Teori ini dikemukakan oleh Peacock dan Wiseman yang didasari oleh adanya suatu pandangan bahwa pemerintah akan senantiasa untuk memperbesar pengeluarannya sementara masyarakat tidak suka membayar pajak untuk membiayai pengeluaran pemerintah yang semakin membesar. Peacock dan Wiseman beranggapan bahwa masyarakat memiliki tingkat tolereansi untuk memahami bahwa besarnya pungutan pajak yang dibutuhkan oleh pemerintah digunakan untuk membiayai pengeluaran pemerintah. Adapun tujuan dari pengeluaran pemerintahan adalah selain untuk penyelenggaraan pemerintahan itu sendiri juga untuk meningkatkan kesejahteraan masyarakat seperti penyediaan pelayanan publik yang sesuai standar. Sehingga masyarakat akhirnya memiliki kesediaan untuk membayar pajak karena pemerintah memerlukan dana untuk membiayai aktivitas pemerintah (Iskandar, 2012).

\section{Transfer}

Transfer adalah dana perimbangan yang berasal dari pendapatan APBN dan dialokasikan kepada daerah untuk mendanai kebutuhan daerah dalam rangka desentralisasi. Mulyana.,dkk dalam Iskandar (2012) menyatakan bahwa terdapat paling tidak lima alasan mengapa transfer dari pemerintah pusat sangat dibutuhkan, yaitu untuk menjaga serta menjamin tercapainya standar 
pelayanan publik minimum, mengurangi kesenjangan keuangan antar daerah, mengurangi kesenjangan vertikal antara pusat dan daerah, mengatasi persoalan efek pelayanan publik antar daerah, dan untuk menciptakan aktifitas perekonomian yang stabil.

Sementara itu menurut BPPK (2006), transfer dari pemerintah pusat dapat dikategorikan menjadi dua bagian yaitu transfer tanpa syarat (unconditional grants) dan transfer bersyarat (conditional grants). Transfer tanpa syarat diberikan untuk menjamin pemerataan kemampuan fiskal antardaerah, sehingga masing-masing daerah dapat melaksanakan urusan rumah tangga daerahnya pada tingkat layak. Transfer ini memiliki ciri utama yaitu adanya keluasaan (diskresi) penuh dalam pemanfaatan dana sesuai dengan kebutuhan atau prioritas daerahnya sendiri. Adapun transfer dengan syarat dignakan untuk kebutuhan yang dianggap penting oleh pemerintah pusat tetapi belum tentu dianggap penting oleh daerah. Adapun transfer tanpa syarat berupa dana alokasi umum (DAU) dan Dana Bagi Hasil (DBH). Sementara transfer bersyarat berupa dana alokasi khusus (DAK).

\section{Otonomi Daerah}

UU Nomor 32 Tahun 2004 Pasal 1 mendefiniskan otonomi daerah sebagai hak, wewenang, dan kewajiban daerah otonom untuk mengatur dan mengurus sendiri urusan pemerintahan dan kepentingan masyarakat setempat sesuai dengan peraturan perundang-undangan. Salawali.,dkk (2016) menyatakan bahwa tujuan diberikannya otonomi daerah adalah untuk memberikan peluang kepada daerah dalam mengatur dan mengurus rumah tangganya sendiri untuk meningkatkan daya guna dan hasil guna penyelenggaraan pemerintahan bagi pelayanan publik dan pelaksanaan pembangunan.

\section{Desentralisasi Fiskal}

UU Nomor 33 Tahun 2004 tentang Perimbangan Keuangan antara Pemerintah Pusat dan Pemerintah Daerah menyebutkan bahwa desentralisasi adalah penyerahan wewenang oleh pemerintah pusat kepada daerah otonom untuk mengatur dan mengurus urusan pemerintahan dalam sistem Negara Kesatuan Republik Indonesia (NKRI). Salah satu wujud penerapan desentralisasi fiskal di Indonesia adalah dibuatnya Anggaran Pendapatan Belanja Daerah (APBD), yaitu suatu instrumen kebijakan fiskal utama untuk menunjukkan kapasitas dan kemampuan daerah (Salawali., dkk, 2016).

\section{Flypaper Effect}

Flypaper effect menurut Iskandar (2012) adalah suatu keadaan dimana pengeluaran pemerintah yang disebabkan oleh dana transfer memiliki stimulus yang lebih besar dibanding dengan pengeluaran pemerintah yang disebabkan oleh pendapatan sendiri. Nurdini.,dkk (2014) menyatakan flypaper effect terjadi apabila pengaruh yang diberikan oleh dana perimbangan atau dana transfer (DAU, DAK, dan DBH) terhadap belanja daerah lebih besar dibandingkan dengan pengaruh yang diberikan oleh PAD terhadap belanja daerah.

\section{Pengaruh DAU terhadap Belanja Daerah}

Pengalokasian DAU di daerah tertentu didasarkan pada besar/kecil suatu celah fiskal (fiscal gap)yang terdapat disuatu daerah, yang merupakan selisih antara kebutuhan daerah (fiscal need) dan potensi daerah (fiscal capacity). Daerah dengan potensi fiskal besar tetapi kebutuhan fiskalnya kecil akan memperoleh alokasi DAU yang relatif lebih kecil. Begitu juga sebaliknya, daerah yang memiliki potensi fiskal kecil tetapi kebutuhan fiskalnya besar, akan memperoleh alokasi DAU yang relatif besar. Semakin besar kebutuhan fiskal suatu daerah, maka belanja daerah di daerah tersebut akan semakin besar pula (Nurdini.,dkk, 2014). Apabila terjadi peningkatan terhadap jumlah alokasi 
dana DAU, maka belanja daerah yang dikeluarkan oleh pemerintah juga ikut meningkat (Jolianis, 2014).

Penelitian yang dilakukan oleh Jolianis (2014), Kusumadewi dan Rahman (2007), Iskandar (2012), Amalia.,dkk (2015) menyatakan bahwa hubungan antara DAU terhadap belanja adalah positif. Berdasarkan penjelasan tersebut, maka rumusan hipotesis pada penelitian ini adalah:

$\boldsymbol{H}_{\boldsymbol{I}} \quad$ : DAU berpengaruh positif terhadap belanja daerah pada Provinsi di Indonesia.

\section{Pengaruh DAK terhadap Belanja Daerah}

DAK merupakan salah satu bagian dari dana transfer yang nilainya relatif lebih kecil serta hanya dapat digunakan dalam hal mendanai kegiatan khusus yang merupakan bagian dari program prioritas nasional yang menjadi urusan daerah. DAK dialokasikan untuk membiayai kebutuhan sarana dan prasarana publik yang belum mencapai standar tertentu, atau berguna untuk mempercepat pembangunan di suatu daerah. Hal tersebut memiliki arti bahwa DAK sebagai salah satu bagian dari pendapatan daerah diperlukan untuk mencukupi kebutuhan pengeluaran belanja daerah yang bersifat lebih spesifik (Amalia, dkk, 2015).

Hasil penelitian yang dilakukan oleh Khoiri dan Hasan (2015), Amalia. dkk (2015), Liando (2017), Yulina. dkk (2017), Rosminar. dkk (2017) menyatakan bahwa DAK secara signifikan berpengaruh terhadap Belanja Daerah dengan arah positif. Belanja daerah akan meningkat ketika DAK yang dialokasikan juga meningkat. Berdasarkan penjelasan tersebut, maka hipotesis yang dapat dirumuskan adalah:

\section{H: $\quad$ DAK berpengaruh positif terhadap Belanja Daerah pada Provinsi di Indonesia.}

\section{Pengaruh DBH terhadap Belanja Daerah}

Dana Bagi Hasil (DBH) merupakan salah satu penerimaan daerah yang dananya bersumber dari pajak dan sumber daya alam, besarnya DBH tergantung pada kontribusi pemerintah daerah dalam menghasilkan pendapatan yang berasal dari pajak daerah dan sumber daya alamnya. Adapun DBH yang diterima pemerintah daerah memiliki persentase penerimaan yang lebih besar dibandingkan pemerintah pusat. DBH nantinya akah digunakan oleh setiap daerah untuk pembangunan dan peningkatan kesejahteraan masyarakat, yang direalisasikan melalui belanja daerah. Jadi, semakin besar DBH maka akan semakin besar pula belanja daerahnya (Nurdini.,dkk, 2014).

Penelitian oleh Yusriadi (2010), Sasana (2010), Sukartono (2010), Iskandar (2012), serta Basri dan Riswandi (2014) menyatakan bahwa DBH berpengaruh positif terhadap belanja daerah. Berdasarkan penjelasan tersebut, maka hipotesis yang dapat dirumuskan adalah:

\section{$H_{3:} \quad$ DBH berpengaruh positif terhadap belanja daerah pada Provinsi di Indonesia}

\section{Pengaruh PAD terhadap Belanja Daerah}

Hipotesis yang dikemukakan oleh Maimunah dan Akbar (2008) menyatakan bahwa pendapatan asli daerah (terutama pajak) akan memberi pengaruh terhadap pengeluaran anggaran belanja pemerintah daerah, atau yang lebih dikenal dengan nama tax spend hypothesis. Daerah yang memiliki PAD tinggi akan memiliki pengeluaran untuk alokasi belanja daerah yang tinggi pula (Jolianis, 2014). Semakin tinggi PAD yang diperoleh oleh daerah tersebut, semakin tinggi pula kemampuan daerah dalam rangka memenuhi kebutuhannya sendiri tanpa bergantung kepada pemerintah pusat (Nurdini, 2014). 
Hasil penelitian Iskandar (2012), Sasana (2010), Salawali. dkk (2015), dan Khoiri dan Hasan (2015) dimana PAD berpengaruh positif terhadap belanja daerah. Berdasarkan penjelasan tersebut, maka hipotesis yang dapat diajukan adalah:

\section{$\boldsymbol{H}_{4}$ : PAD berpengaruh positif terhadap belanja daerah pada Provinsi di Indonesia.}

\section{Pengaruh PDRB terhadap Belanja Daerah}

PDRB memiliki hubungan fungsional dengan PAD, dikarenakan PDRB merupakan fungsi dari PAD. Semakin tinggi PDRB perkapita di suatu daerah, maka potensi sumber penerimaan di daerah tersebut juga akan semakin tinggi (Thamrin dalam Iskandar, 2012).

Pertumbuhan ekonomi yang dicerminkan melalui PDRB merupakan salah satu tujuan penting dari pemerintah pusat dan daerah yang mendorong dilakukannya pembangunan ekonomi. Pembangunan perekonomian dapat ditandai dengan adanya peningkatan terhadap produktivitas dan pendapatan perkapita penduduk yang mendorong terjadinya perbaikan kesejahteraan yang dapat dircerminkan dengan peningkatan pelayanan publik baik sarana maupun prasarana yang dapat menunjang kegiatan perekonomian. Hal tersebut direalisasikan melalui belanja daerah. Apabila pertumbuhan ekonomi meningkat, maka akan meningkatkan meningkatkan belanja daerah untuk memperbaiki dan melengkapi sarana dan prasarana sehingga pertumbuhan ekonomi kedepannya akan semakin membaik (Jaya dan Dwirandra, 2014).

Penelitian Sasana (2011) menyatakan bahwa PDRB berpengaruh positif terhadap belanja daerah Kabupaten/Kota di Jawa Barat. Penelitian serupa yang dilakukan oleh yang dilakukan oleh Maimunah dan Akbar (2008), menyatakan bahwasanya PDRB berpengaruh positif terhadap belanja daerah. Berdasarkan penjelasan tersebut, maka hipotesis yang diajukan adalah:

\section{$\boldsymbol{H}_{5} \quad$ : PDRB berpengaruh positif terhadap belanja daerah pada Provinsi di Indonesia.}

\section{Flypaper Effect terhadap Belanja Daerah}

Flypaper effect menurut Iskandar (2012) adalah suatu keadaan dimana stimulus terhadap belanja daerah yang disebabkan oleh perubahan dana transfer dari pemerintah pusat lebih besar daripada stimulus yang disebabkan oleh pednapatan asli daerahnya. Nurdini. dkk (2014) menyatakan apabila PAD memberikan pengaaruh yang lebih besar terhadap belanja daerah disbanding pengaruh yang diberikan oleh dana perimbangan (DAU, DAK, DBH) terhadap belanja daerah dinamakan flypaper effect. Sementara hal tersebut bertentangan dengan konsep desentralisasi dan otonomi daerah yang menuntut pemerintah daerah untuk lebih mandiri dan tidak terlalu bergantung pada pemerintah pusat (Iskandar, 2012). Menurut Jatmiko (2016) terjadinya flypaper effect mencerminkan bahwa daerah tersebut merupakan daerah belum mandiri.

Penelitian yang dilakukan oleh Sasana (2010) menunjukkan hasil bahwa terjadi flypaper effect, artinya belanja daerah lebih didominasi oleh DAU daripada PAD atau respon belanja daerah terhadap penerimaan DAU berbeda dengan penerimaan PAD. Hal ini sejalan dengan penelitian Nurdini.,dkk (2014), Iskandar (2012), Salawali.,dkk (2016) dan Jatmiko (2016) yang menyatakan bahwa terjadi flypaper effect pada masing-masing daerah yang diteliti. Berdasarkan penjelasan diatas, maka hipotesis yang diajukan adalah:

$\boldsymbol{H}_{\sigma} \quad$ : Terjadi flypaper effect terhadap belanja daerah pada Provinsi di Indonesia.

\section{METODE PENELITIAN}

Metode penelitian yang digunakan dalam penelitian ini adalah metode deskriptif yang bertujuan untuk membuat deskripsi secara sistematis, faktual, serta akurat terhadap fakta. Subyek 
atau populasi yang diteliti adalah Provinsi yang ada di Indonesia sampai tahun 2016. Obyek yang diteliti pada penelitian ini adalah data variabel Dana Alokasi Umum (DAU), Dana Alokasi Khusus (DAK), Dana Bagi Hasil (DBH), Pendapatan Asli Daerah (PAD), dan Produk Domestik Regional Bruto (PDRB) sebagai variabel independen. Variabel dependen menggunakan data variabel Belanja Daerah pada laporan realisasi Anggaran Pendapatan dan Belanja Daerah (APBD). Jenis data yang digunakan dalam penelitian ini adalah data sekunder. Data sekunder merupakan data yang sudah tersedia dan dikumpulkan oleh pihak-pihak lain. Data yang diambil penelitian ini berasal dari laporan realisasi APBD Provinsi tahun 2014-2016 dan data laju pertumbuhan PDRB tahun 2013-2015. Data tersebut akan digunakan untuk mendukung variabel-variabel yang digunakan dalam penelitian ini. Teknik pengambilan sampel yang digunakan adalah purposive sampling yang menggunakan pertimbangan tertentu, yaitu:

1. Pemerintah provinsi yang telah mempublikasikan laporan realisasi APBD selama 3 tahun berturut-turut yaitu 2014-2016.

2. Pemerintah provinsi di Indonesia yang memiliki data PDRB selama tahun 2013-2015 pada website Badan Pusat Statistik (BPS).

Pengumpulan data dalam peneltian ini menggunakan metode dokumentasi dengan cara mengumpulkan seluruh data sekunder dan seluruh informasi yang digunakan untuk menyelesaikan masalah-masalah yang ada dalam penelitian ini. Pengambilan data laporan realisasi APBD pada website Departemen Keuangan Dirjen Perimbangan Keuangan Pusat dan Daerah yaitu www.djpk.depkeu.go.id dan data PDRB pada website Badan Pusat Statistik (BPS) yaitu www.bps.go.id. Metode analisis data yang digunakan adalah analisis regresi linier berganda dengan menggunakan SPSS. Metode analisis data digunakan dalam penelitian ini sebagai prosedur atau teknik untuk menguji hipotesis yang telah diajukan. Adapun metode yang digunakan adalah analisis statistik deskriptif, uji asumsi klasik (uji normalitas, uji multikolinearitas, uji autokorelasi, uji heteroskedastisitas). Sementara uji hipotesis dalam penelitian ini menggunakan analisis regresi linear berganda, uji t, uji f, dan uji koefisien determinasi.

\section{HASIL DAN PEMBAHASAN}

Berdasarkan kriteria yang telah dijelaskan dalam Bab III, dari total 34 provinsi di Indonesia yang tercatat dalam Kemendagri sampai dengan tahun 2016, diperoleh hasil pemilihan sampel sebanyak 32 Provinsi. Hal ini dikarenakan terdapat 2 Provinsi yang belum mempublikasikan APBD Provinsinya, yaitu Sulawesi Tenggara dan Bali di tahun 2016.

Data yang diambil dari laporan realisasi APBD setiap daerah adalah PAD dan dana perimbangan (DAU, DAK, dan DBH). Berikut adalah komposisi perbandingan PAD dan dana perimbangan pada 32 Provinsi di Indonesia tahun 2014-2016.

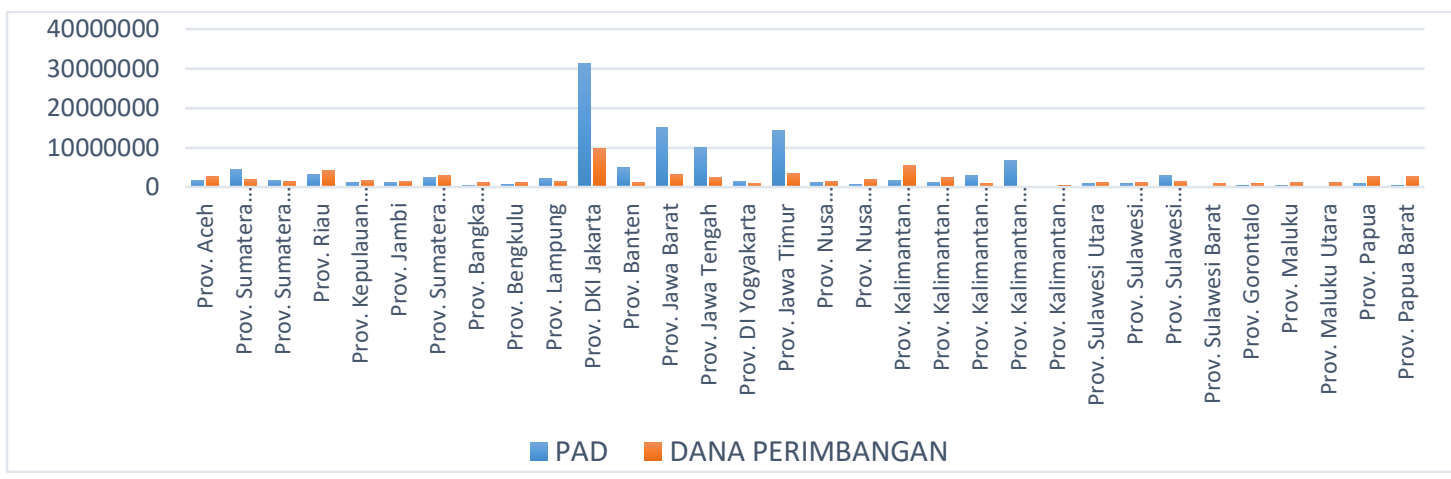

Gambar 4 Perbandingan PAD dan Dana Perimbangan Provinsi di Indonesia Tahun 2014 Sumber: Data diolah dari Laporan Realisasi APBD Tahun 2014 
Berdasarkan gambar diatas dapat dilihat bahwa pada tahun 2014, komposisi PAD pada beberapa provinsi jauh lebih besar dibandingkan dengan komposisi dana perimbangan, seperti Provinsi DKI Jakarta, Jawa Barat, dan Jawa Timur. Sementara beberapa Provinsi lainnya memiliki komposisi dana perimbangan lebih besar dibandingkan dengan komposisi PAD, seperti Provinsi Aceh, Riau, Kalimantan Barat, Papua, dan Papua Barat.

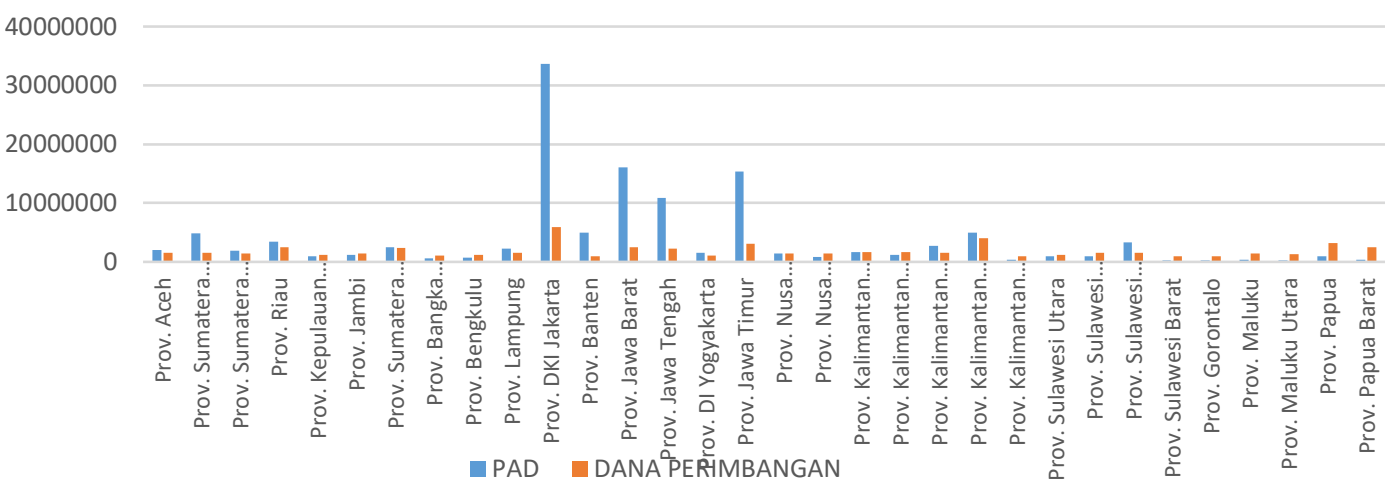

Gambar 5 Perbandingan PAD dan Dana Perimbangan Provinsi di Indonesia Tahun 2015 Sumber: Data diolah dari Laporan Realisasi APBD Tahun 2015

Berdasarkan data dari gambar diatas, dapat dilihat bahwa ada beberapa Provinsi yang mengalami penurunan dana perimbangan dan peningkatan jumlah PAD yang cukup signifikan dari tahun sebelumnya, yaitu seperti Provinsi DKI Jakarta, Jawa Barat, Jawa Tengah dan Jawa Timur. Selain itu masih ada beberapa Provinsi yang komposisi dana perimbangannya lebih besar dibandingkan dengan komposisi PAD

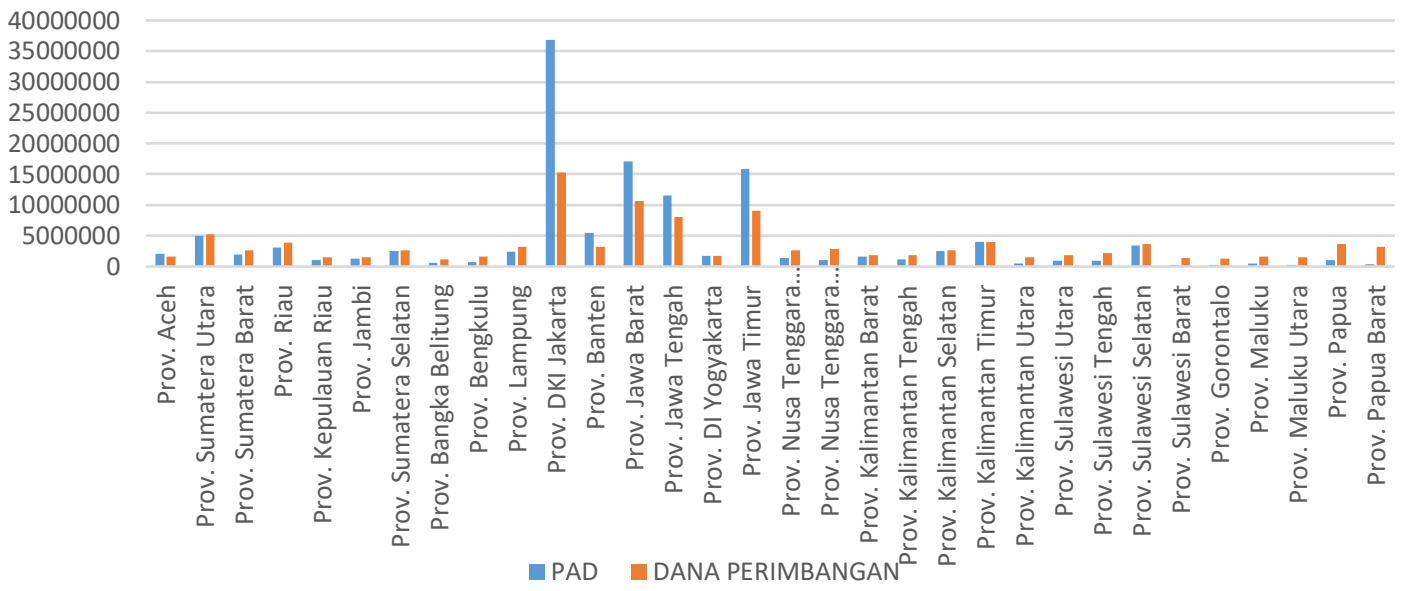

Gambar 6. Perbandingan PAD dan Dana Perimbangan Provinsi di Indonesia Tahun 2016 Sumber: Data diolah dari Laporan Realisasi APBD Tahun 2016

Berdasarkan gambar diatas serta perbandingan di dua gambar sebelumnya yaitu tahun 2015 dan 2014, dapat dilihat ada beberapa provinsi yang memiliki jumlah PAD lebih besar dibandingkan dengan dana perimbangan, sebaliknya di beberapa provinsi lainnya jumlah dana perimbangan lebih besar disbanding jumlah PAD. Sehingga peneliti belum dapat menyimpulkan apakah terjadi flypaper effect pada Provinsi di Indonesia. Oleh sebab itu diperlukan pengujian menggunakan data semua variabel agar dapat diketahui terjadi atu tidaknya flypaper effect.

Penelitian terhadap 32 Provinsi di Indonesia selama 3 tahun berturut-turut menghasilkan 96 data yang dapat diolah, dalam proses pengolahan data terdapat 17 data provinsi yang mengalami outlier sehingga data yang dapat diolah adalah sebanyak 79 data provinsi. Peneliti melakukan logaritma data pada variabel DAU, DAK, DBH, PAD, dan belanja daerah. Hal tersebut 
dikarenakan data lima variabel tersebut memiliki rentang nilai yang sangat jauh terhadap data PDRB.

\section{Statistik Deskriptif}

Uji statistik deskriptif yang disajikan dalam penelitian ini adalah mengenai nilai minimum, nilai maksimum, nilai rata-rata (mean) dan standard deviation untuk variabel DAU, DAK, DBH, PAD (dalam jutaan rupiah) dan PDRB serta variabel dependennya yaitu belanja daerah (BD). Hasil uji statistik deskriptif disajikan dalam tabel dibawah ini:

Tabel 1 Descriptive Statistics

\begin{tabular}{llllll}
\hline & N & Minimum & Maximum & Mean & Std. Deviation \\
\hline DAU & 79 & 20568.00 & 1866548.00 & 1042815.3418 & 346210.36682 \\
DAK & 79 & 1038.00 & 7596342.00 & 542547.0633 & 1261587.93907 \\
DBH & 79 & 20767.00 & 4194971.00 & 555585.7215 & 785830.74243 \\
PAD & 79 & 11834.00 & 17042895.00 & 2688954.4304 & 3616014.63786 \\
PDRB & 79 & -10.15 & 12.52 & 4.9881 & 3.57085 \\
BD & 79 & 642365.00 & 27621964.00 & 4953792.3038 & 4701976.06384 \\
Valid N (listwise) & 79 & & & & \\
\hline
\end{tabular}

\section{Hasil Pengujian Hipotesis}

Sebelum dilakukan pengujian hipotesis menggunakan analisis regresi linier berganda, terlebih dahulu dilakukan uji asumsi klasik yang terdiri dari uji normalitas, uji heteroskedastisitas, uji autokorelasi serta uji multikolinearitas (Nazaruddin dan Basuki, 2017). Data yang digunakan dalam penelitian ini sudah lolos dari uji asumsi klasik yang kemudian dilakukan uji regresi linier berganda untuk pengujian hipotesis dengan hasil sebagai berikut:

Tabel 2 Hasil Uji Analisis Regresi Linier Berganda

\begin{tabular}{|c|c|c|c|c|c|c|}
\hline \multirow{2}{*}{\multicolumn{2}{|c|}{ Model }} & \multicolumn{2}{|c|}{ Unstandardized Coefficients } & \multicolumn{2}{|c|}{$\begin{array}{l}\text { Standardized } \\
\text { Coefficients }\end{array}$} & \multirow[b]{2}{*}{ Sig. } \\
\hline & & B & Std. Error & Beta & $\mathbf{T}$ & \\
\hline \multirow[t]{6}{*}{1} & (Constant) & 7.064 & .503 & & 14.036 & .000 \\
\hline & DAU_LN & -.038 & .040 & -.035 & -.938 & .352 \\
\hline & DAK_LN & .096 & .015 & .209 & 6.525 & .000 \\
\hline & DBH_LN & .058 & .020 & .106 & 2.891 & .005 \\
\hline & PAD_LN & .486 & .023 & .822 & 20.715 & .000 \\
\hline & PDRB & -.030 & .007 & -.149 & -4.348 & .000 \\
\hline
\end{tabular}

a. Dependent Variable: Belanja Daerah (BD_LN)

Sumber: Output SPSS 16, 2018

Berdasarkan tabel 2 diatas, diperoleh persamaan regresi sebagai berikut:

$\mathrm{BD}=7,064-0,038 \mathrm{X}_{1}+0,096 \mathrm{X}_{2}+0,058 \mathrm{X}_{3}+0,486 \mathrm{X}_{4}-0,030 \mathrm{X}_{5}+\mathrm{e}$

\section{Dana Alokasi Umum terhadap Belanja Daerah}

Hasil pengujian hipotesis menunjukkan bahwa variabel Dana Alokasi Umum tidak berpengaruh terhadap belanja daerah dengan nilai sig $0,352>\alpha(0,05)$ dan bertanda negatif. Dana Alokasi Umum adalah dana perimbangan yang bersumber dari APBN yang pengalokasiannya bertujuan untuk meratakan kemampuan keuangan antar daerah guna membiayai kebutuhan 
pengeluarannya sebagai bentuk pelaksanaan desentralisasi. Akan tetapi menurut Iskandar (2012) adanya DAU memberikan dampak yang tidak baik terkait aliran transfer, karena pemerintah daerah cenderung menggunakan DAU dengan jumlah yang lebih besar dibandingkan menggunakan dana asli daerahnya untuk membiayai kebutuhan belanja. Sementara hal ini bertentangan dengan prinsip desentralisasi yang mengharapkan kemandirian dari setiap daerah dengan tidak lagi bergantung kepada pemerintah pusat. Ditolaknya hipotesis pertama menunjukkan bahwa pemerintah provinsi tidak lagi menggunakan DAU sebagai sumber utama untuk membiayai kebutuhan belanja.

Penelitian ini mendukung penelitian-penelitian sebelumnya yang dilakukan oleh Susilo dan Adi (2007), Shiddieqy dan Afriana (2013), Nur (2015), Sriwahyuni (2010) dan Setyorini (2013).

\section{Dana Alokasi Khusus terhadap Belanja Daerah}

Hasil pengujian hipotesis kedua menunjukkan bahwa Dana Alokasi Khusus berpengaruh positif terhadap belanja daerah pada Provinsi di Indonesia dengan nilai sig sebesar $0,000<\alpha(0,05)$ dan bertanda positif. Dana Alokasi Khusus hanya digunakan untuk membiayai kebutuhan belanja yang menjadi prioritas nasional dan menjadi urusan daerah yang berkaitan dengan kesejahteraan rakyat, seperti belanja untuk pelayanan publik serta pengadaan sarana dan prasarana yang memadai sehingga nantinya para investor tertarik untuk menanamkan modalnya di daerah tersebut. Semakin banyak investor yang menanamkan modalnya, maka dapat meningkatkan pendapatan daerah yang dapat digunakan untuk membiayai kebutuhan daerahnya, sehingga peluang daerah tersebut untuk lebih berkembang akan semakin besar.

Hasil penelitian ini mendukung penelitian sebelumnya yaitu Khoiri dan Hasan (2015), Liando (2017), Amalia. dkk (2015), Sasana (2011) dan Yuliana. dkk (2017).

\section{Dana Bagi Hasil terhadap Belanja Daerah}

Hasil pengujian hipotesis ketiga menunjukkan bahwa Dana Bagi Hasil berpengaruh positif terhadap belanja daerah pada provinsi di Indonesia dengan nilai sig sebesar $0,005<\alpha(0,05)$, dan bertanda positif. Dana Bagi Hasil (DBH) merupakan salah satu dana perimbangan yang berasal dari pendapatan APBN dan pengalokasiannya berbeda dengan DAU dan DAK, yaitu didasarkan pada angka persentase bagi hasil sesuai dengan kontribusi pemerintah daerah terhadap pemerintah pusat yang sumbernya berasal dari pajak dan sumber daya alam masing-masing daerah di Indonesia.

Oleh sebab itu, besarnya alokasi DBH didasarkan pada keberhasilan suatu daerah dalam penghasilan pajak dan sumber daya alam daerahnya masing-masing. Apabila suatu daerah mendapat penghasilan pajak daerah dan hasil pengelolaan sumber daya alam yang besar, maka penerimaan alokasi DBH juga akan besar. Begitu pula sebaliknya apabila penghasilan pajak daerah dan hasil pengelolaan sumber daya alam kecil, maka DBH yang diterima juga kecil.

Potensi yang dimiliki setiap Provinsi yang ada di Indonesia berbeda-beda,sehingga pendapatan DBH disetiap Provinsi juga berbeda-beda. Hasil dari penerimaan DBH dapat digunakan untuk meningkatkan pembangunan dan kesejahteraan masing-masing daerah. Pembangunan serta pengeluaran lain yang ada hubungannya dengan pengelolaan kekayaan daerah akan memberikan pengaruh terhadap besarnya belanja daerah. Sehingga semakin besar DBH, maka akan semakin besar pula belanja daerahnya.

Penelitian ini mendukung penelitian-penelitian yang telah dilakukan sebelumya, yaitu Mulyati dan Yusriadi (2017), Nurdini. dkk (2014), Sukartono (2010), Basri dan Riswandi (2014), Sasana (2010), Inayati dan Setiawan (2017), dan Iskandar (2012).

\section{Pendapatan Asli Daerah terhadap Belanja Daerah}

Hasil pengujian hipotesis keempat menunjukkan bahwa Pendapatan Asli Daerah berpengaruh positif terhadap belanja daerah pada provinsi di Indonesia dengan nilai sig sebesar $0,000<\alpha(0,05)$ dan bertanda positif. Pendapatan Asli Daerah (PAD) merupakan salah satu sumber 
penerimaan daerah yang digunakan untuk memenuhi kebutuhan belanja daerah. Belanja daerah dilakukan oleh Pemerintah Daerah untuk kegiatan penyelenggaraan pemerintahan, pembangunan daerah, pelayanan publik, dan peningkatan perekonomian daerah sehingga dapat menyejahterahkan masyarakatnya yang merupakan wujud dari pelaksanaan desentralisasi.

Diterapkannya desentralisasi di Indonesia menuntut setiap pemerintah daerah untuk menjadi daerah yang mandiri dan tidak bergantung pada Pemerintah Pusat. Menurut Halim (2007) untuk meminimalkan ketergantungan daerah kepada pusat, maka Pendapatan Asli Daerah harus menjadi sumber keuangan terbesar dalam hal membiayai kebutuhan belanja daerah. Oleh sebab itu, semakin besar anggaran belanja daerah, semakin besar pula PAD yang harus dimiliki oleh daerah tersebut.

Peningkatan jumlah PAD pada Provinsi di Indonesia setiap tahunnya menggambarkan mengenai kinerja daerah yang juga meningkat setiap tahunnya dalam menggali potensi yang dimiliki oleh daerahnya untuk dijadikan PAD. Salah satu sumber PAD terbesar adalah pajak daerah, sehingga apabila terjadi peningkatan PAD maka kesadaran wajib pajak untuk membayarkan pajaknya juga meningkat. Selanjutnya tugas pemerintah daerah adalah memperbaiki fasilitas publik sehingga masyarakat mendapatkan manfaat dari pajak yang telah dibayarkan.

Hasil penelitian ini konsisten dan sejalan dengan penelitian sebelumnya yang dilakukan oleh Maimunah dan Akbar (2008), Nurdini. dkk (2014), Iskandar (2012), Jolianis (2014), Sasana (2010), Kusumadewi dan Rahman (2007), Afrizawati (2012), Khoiri dan Hasan (2015).

\section{Produk Domestik Regional Bruto terhadap Belanja Daerah}

Hasil pengujian hipotesis kelima menunjukkan bahwa Produk Domestik Regional Bruto (PDRB) tidak berpengaruh terhadap belanja daerah pada Provinsi di Indonesia dengan nilai sig sebesar $0,000<\alpha(0,05)$ dan koefisien regresi bertanda negatif. Ditolaknya hipotesis kelima mungkin disebabkan oleh pertumbuhan ekonomi yang tidak terlalu signifikan sehingga tidak menghasilkan sumber pendapatan yang dapat dialokasikan untuk alokasi belanja. Selain itu hal ini juga bukan berarti bahwa pertumbuhan ekonomi yang dicerminkan oleh PDRB tidak menjadi acuan dalam proses penyusunan anggaran belanja dalam APBD. Karena menurut Tuasikal (2008) terdapat faktor-faktor tertentu lain yang dapat mempengaruhi anggaran belanja seperti proses penyusunan Kebijakan Umum Anggaran (KUA) disetiap daerah yang selain memperhatikan kondisi makro ekonomi daerahnya juga memperhatikan kondisi politik dan sosial di daerahnya.

Selain itu, pada tabel 1. statistik deskritif dapat dilihat bahwa rata-rata pertumbuhan ekonomi selama 3 tahun adalah 4,9881\%. Dimana persentase perumbuhan ekonomi masih rendah, sehingga wajar saja bila PDRB tidak berpengaruh positif terhadap belanja daerah. Hasil penelitian ini mendukung penelitian sebelumnya oleh Dewi dan Suyanto (2015). Hasil penelitiannya membuktikan bahwa pertumbuhan ekonomi yang dicerminkan melalui PDRB tidak berpengaruh terhadap belanja modal. Hal ini dikarenakan pertumbuhan ekonomi dapat tercipta dari infrastruktur atau sarana dan prasarana yang baik, dimana sarana dan prasarana maupun infrastruktur berasal dari belanja modal. Sementara dalam penelitian ini, pemerintah daerah tidak mengalokasikan belanja modalnya tepat sasaran.

Penelitian ini mendukung penelitian sebelumnya yang dilakukan oleh Tuasikal (2008), Jaya dan Dwirandra (2014), Darwanto dan Yustika (2007), Putro (2010) dan Adiwiyana (2011).

\section{Koefisien Determinasi}

Tabel 3 Hasil Uji Koefisien Determinasi

\begin{tabular}{|c|c|c|c|c|}
\hline Model & $\mathrm{R}$ & R Square & Adjusted R Square & Std. Error of the Estimate \\
\hline 1 & $.969^{\mathrm{a}}$ & .940 & .936 & .18035 \\
\hline
\end{tabular}

Sumber: Output SPSS 16, 2018 
Berdasarkan tabel diatas, nilai adjusted $R^{2}$ adalah sebesar 0,936 yang berarti bahwa 93,6\% variabel belanja daerah dapat dijelaskan oleh 5 variabel independen Dana Alokasi Umum (DAU), Dana Alokasi Khusus (DAK), Dana Bagi Hasil (DBH), Pendapatan Asli Daerah (PAD) dan Produk Domestik Regional Bruto (PDRB). Sementara itu sisanya (100\% - 93,6\% =6,4\%) dijelaskan oleh variabel lain diluar model penelitian. disajikan dalam tabel dibawah ini.

Tabel 4 Perbandingan hasil uji koefisien Determinasi DAU, DAK, dan DBH dengan PAD terhadap Belanja Derah

\begin{tabular}{ll}
\hline Variabel & Adjusted R Square \\
\hline DAU & \\
DAK & .497 \\
DBH & \\
PAD & .898 \\
\hline
\end{tabular}

Sumber: Data sekunder yang diolah, 2018

\section{Flypaper Effect terhadap Belanja Daerah}

Uji koefisien determinasi juga digunakan untuk menguji hipotesis keenam (H_6) terjadi atau tidaknya flypaper effect pada provinsi di Indonesia. Menurut Nurdini.,dkk, (2014) pengujian flypaper effect dilakukan dengan cara membandingkan nilai adjusted R Square variabel DAU, DAK, dan DBH dengan nilai nilai adjusted $\mathrm{R}$ Square variabel PAD. Jika nilai adjusted R Square variabel DAU, DAK, dan DBH lebih besar, maka hipotesis keenam (H_6) diterima. Hasil perbandingan antara uji koefisien determinasi (DAU, DAK, dan DBH) dengan PAD terhadap belanja daerah berpengaruh terhadap belanja daerah sebesar 49,7\%. Sementara itu, nilai adjusted $\boldsymbol{R}$ Square PAD terhadap belanja daerah adalah sebesar 0,898 yang memiliki arti bahwa PAD berpengaruh terhadap belanja daerah sebesar $89,8 \%$.

Berdasarkan hasil dari perbandingan tersebut, dapat dilihat pengaruh simultan DAU, DAK, dan DBH terhadap belanja daerah lebih kecil dibanding pengaruh PAD terhadap belanja daerah $(0,497<0,898)$. Sehingga hipotesis keenam $\left(\mathrm{H}_{6}\right)$ ditolak, dan menyatakan bahwa tidak terjadi fenomena flypaper effect pada provinsi di Indonesia. Flypaper effect adalah suatu keadaan dimana pengaruh yang diberikan oleh dana perimbangan (DAU, DAK, DBH) terhadap belanja daerah lebih besar dibandingkan pengaruh yang diberikan oleh PAD terhadap belanja daerah. Hal ini tentu saja bertentangan dengan asas desentralisasi dan prinsip otonomi yang menuntut kemandirian pemerintah daerah agar tidak bergantung pada pemerintah pusat.

Berdasarkan hasil penelitian yang dilakukan di 32 Provinsi yang ada di Indonesia, ditemukan fakta bahwa tidak terjadi flypaper effect yang mencerminkan bahwa selama tahun 2014-2016 secara umum provinsi di Indonesia telah mandiri dari segi keuangannya karena sudah mampu bertumpu pada keuangan daerahnya sendiri dalam menjalankan roda pemerintahan, dikarenakan pemerintah provinsi pada tahun 2014-2016 telah mampu mengoptimalkan PAD yang kemudian dijadikan sumber utama dalam membiayai kebutuhan belanja daerahnya.

Penelitian ini mendukung penelitian Kang dan Setyawan (2012), Liando (2017), Khoiri dan Hasan (2015), Rahmawati (2015), dan Mentayani. dkk (2015).

\section{KETERBATASAN PENELITIAN}

Peneliti menyadari bahwa masih banyak terdapat kelemahan dan kekuarangan dalam penelitian ini. Disebabkan oleh adanya beberapa keterbatasan penelitian, diantaranya informasi yang ada dalam penelitian ini kurang lengkap, karena dalam pengujian hipotesisnya hanya menggunakan data yang diambil dari laporan realisasi APBD masing-masing Provinsi, sehingga tidak diikuti dengan realita ataupun permasalahan yang sebenarnya terjadi pada Provinsi tersebut. Kurangnya variabel-variabel yang menyebabkan terjadinya peningkatan maupun penurunan terhadap PAD dan Dana 
Perimbangan. Kurangnya faktor-faktor yang mendukung kalasan kenapa pertumbuhan ekonomi di Indonesia dinilai masih rendah.

\section{KESIMPULAN}

Berdasarkan penelitian terhadap 32 sampel Pemerintah Provinsi yang ada di Indonesia selama tahun 2014-2016, dapat disimpulkan bahwa dana Alokasi Umum dan Produk Domestik Regional Bruto tidak berpengaruh terhadap belanja daerah pada Provinsi di Indonesia. Dana Aokasi Khusus, Dana Bagi Hasil, Pendapatan Asli Daerah berpengaruh positif dan signifikan terhadap belanja daerah pada Provinsi di Indonesia. Dilihat dari nilai Adjusted $R$ Square dana perimbangan (DAU, DAK, DBH) yang lebih kecil dibandingkan dengan Adjusted $R$ Sqiare PAD, disimpulkan tidak terjadi flypaper effect pada Provinsi di Indonesia dalam kurun waktu 2014-2016.

Berdasarkan kesimpulan yang dihasilkan dalam peneltian ini, maka penulis menyampaikan beberapa saran yang diharapkan dapatt berguna untuk penelitian selanjutnya, diantaranya penelitian selanjutnya diharapkan memperbanyak atau memperluas sampel seperti meneliti kabupaten/kota yang ada di Indonesia sehingga hasil penelitiannya diharapkan dapat memberikan pengetahuan mengenai daerah mana saja yang sudah mandiri atau belum. Penelitian selanjutnya diharapkan dapat mempergunakan metode lain dalam penelitiannya seperti wawancara secara langsung dengan pihak terkait dalam penyusunan APBD. Penelitian selanjutnya diharapkan dapat menggunakan variabel independen yang lebih beragam, baik dari segi ukuran atau jenis penerimaan daerah lainnya maupun variabel non keuangan lainnya seperti aspek kebijakan penganggaran pemerintah maupun aspek kebijakan publik. Penelitian selanjutnya disarankan untuk tidak menggunakan data Provinsi DKI Jakarta sebagai sampel penelitian karena DKI Jakarta merupakan Provinsi yang sudah mandiri dengan tidak lagi bergantung pada DAU sejak tahun 2015.

\section{DAFTAR PUSTAKA}

. 1999. Undang -Undang Nomor 25 Tahun 1999 Tentang Perimbangan Keuangan Antara Pusat Dan Daerah. 2004. Undang -Undang Nomor 33 Tahun 2004 Tentang Perimbangan Keuangan Antara Pusat Dan Daerah.

.2004. Undang -Undang Nomor 32 Tahun 2004 Tentang Pemerintah Daerah.

Adiwiyana, Pr. (2011). Pengaruh Pertumbuhan Ekonomi, Pendapatan Asli Daerah, dan Dana Alokasi Umum terhadap Pengalokasian anggaran Belanja Modal. Jurnal Ekonomi dan Bisnis.

Afrizawati. (2012). Analisis Flypaper Effect pada Belanja Daerah Kabupaten/Kota di Sumatra Selatan. Jurnal Ekonomi dan Informasi Akuntansi, 2(1), 21-30.

Amalia, W. R., Wahyudin, N., \& Nordiansyah, M. (2015). Flypaper Effect pada Pendapatan Asli Daerah (PAD), Dana Alokas Umum (DAU) dan Dana Alokasi Khusus (DAK) Terhadap Belanja Daerah pada Pemerintah Kabupaten/Kota di Provinsi Kalimantan Selatan (20092013). Jurnal Akuntansi dan Bisnis, 15(1), 1-12.

Basri, M. H. \& Riswandi. (2014). Apakah Flypaper Effect Terjadi di Aceh? Studi Mengukur Kemandirian Keuangan Daerah. QEJournal, 3(4), 199-216.

Bisnis Indonesia, Dirjen Perimbangan Kemenkeu Boediarso Teguh Widodo: Daerah Harus Lebih Dewasa, http://kalimantan.bisnis.com/read/20170502/250/649674/dirjeniperimbangankeuangan-kemenkeu-boediarso-teguh-widodo-daerah-harus-lebih-dewasa. Diakses pada tanggal 20 Juni 2017.

Darwanto, \& Yustika, Y. (2007). Pengaruh Pertumbuhan Ekonomi, Pendapatan Asli Daerah, dan Dana Alokasi Umum Terhadap Pengalokasian Anggaran Belanja Modal. Simposium Nasional Akuntansi X. 26-28 Juli, Makassar. 
Dewi, S. P., \& Suyanto, S. (2016). Pengaruh Pertumbuhan Ekonomi, Pendapatan Asli Daerah, Dana Alokasi Umum, Dana Alokasi Khusus Terhadap Belanja Modal Pada Provinsi Jawa Tengah. Jurnal Akuntansi, 3(1).

Halim, A. (2007). Akuntansi Keuangan Daerah. Jakarta: Salemba Empat.

Hasan, P.P., \& Permana, B. (2012). Kajian Dampak Desentralisasi Fiskal terhadap Kemandirian Daerah: Studi di Kabupaten dan 3 Kota Provinsi Jawa Barat. Pusat Kajian dan Pendidikan dan Pelatihan Aparatur I (PKP2A I) LAN.

Inayati, N. I., \& Setiawan, D. (2017). Fenomena Flypaper Effect Pada Belanja Daerah Kabupaten/Kota di Indonesia. Ekuitas (Jurnal Ekonomi Dan Keuangan), 1(2), $220-239$.

Iskandar, I. (2012). Flypaper Effect Pada Unconditional Grant. Jurnal Ekonomi Pembangunan, 113-131.

Jatmiko, P. E. R. (2016). Pengaruh Dana Perimbangan Dan Pendapatan Asli Daerah Terhadap Belanja Daerah Pemerintah Kabupaten Dan Kota Di Jawa Timur.Jurnal Ekonomi Pembangunan, 14(1), 46-58.

Jaya, I. P. N.P.K., \& Dwirandra, A. A. N. B. (2014). Pengaruh Pendapatan Asli daerah pada Belanja Modal dengan Pertumbuhan Ekonomi Sebagai Variabel Pemoderasi. E-Jurnal Akuntansi Universitas Udayana, 79-92.

Jolianis, J. (2014). Pengaruh Dana Alokasi Umum (DAU) Dan Pendapatan Asli Daerah (PAD) Terhadap Belanja Daerah Pada Kabupaten/Kota Di Provinsi Sumatera Barat. Jurnal Pelangi, $7(1)$.

Kang, Y., \& Setyawan, D. (2012). Intergovernmental Transfer and The Flypaper Effect-Evidence from Municipalities/Regencies in Indonesia. Regencies in Indonesia.

Khoiri, A., \& Hasan, R. (2015). Flypaper Effect dan Belanja Daerah di Propinsi Jawa Barat. SIGNIFIKAN: Jurnal Ilmu Ekonomi, 4(2).

Kusumadewi, D. A. dan Rahman, A. (2007). Flypaper effect pada dana alokasi umum (DAU) dan pendapatan asli daerah (PAD) terhadap belanja daerah pada kabupaten/kota di Indonesia. Jurnal Akuntansi dan Auditing Indonesia, 11(1).

Liando, I. I. (2017). Faktor-Faktor Yang Mempengaruhi Belanja Daerah Pada Kabupaten/Kota Jawa Timur. Jurnal Ilmu Dan Riset Akuntansi, 6(6).

Maimunah, M. \& Akbar, R. (2008). Flypaper Effect pada Dana Alokasi Umum (DAU) dan Pendapatan Asli Daerah (PAD) terhadap Belanja Daerah pada kabupaten/Kota di pulau Sumatera. Jurnal Riset Akuntansi Indonesia, 1(1), 37-51.

Mentayani, N. H., \& Rusmanto. (2012). Flypaper Effect Pada Dana Alokasi Umum dan Pendapatan Asli Daerah terhadap Belanja Daerah Pada Kota dan Kabupaten di Provinsi Kalimantan Selatan. Jurnal Spread 2(1), 55-64.

Mulyati, S., \& Yusriadi, Y. (2017). Dana Bagi Hasil Dan Dana Alokasi Umum Terhadap Belanja Daerah Pada Provinsi Aceh. Agregat: Jurnal Ekonomi Dan Bisnis, 1(2), 211-220.

Nazaruddin, I., \& Basuki, A. (2017). Praktik Komputer Statistika. UMY, Yogyakarta.

Nur, M. (2015). Pengaruh Pendapatan Asli Daerah, Dana Alokasi Umum, dan Dana Alokasi Khusus terhadap Belanja Daerah di Sulawesi Selatan. In Assets 5(1), 78-88.

Nurdini, R., Wiranto, A., \& Yusriati N. F. (2014). Analisis Flypaper Effect Pada Dana Alokasi Umum (DAU), Dana Alokasi Khusus (DAK), Dana Bagi Hasil (DBH), Dan Pendapatan Asli Daerah (PAD) Terhadap Belanja Daerah (BD) Kabupaten/Kota Di Jawa Barat. Jurnal Akuntansi dan Keuangan, 2(1).

Raharjo, E. (2010). Teori Agensi dan Teori Stewarship Dalam Perspektif Akuntansi. Jurnal Ekonomi

Rahmawati, L. A. (2015). Flypaper Effect Dana Alokasi Umum (DAU) Dan Pendapatan Asli Daerah (PAD) Terhadap Belanja Daerah. Sekolah tinggi ilmu ekonomi Indonesia.

Republik Indonesia. 1999. Undang-Undang Nomor 22 Tahun 1999, Tentang Pemerintah Daerah. Rosminar, R., Khaddafi, M., \& Syamni, G. (2018). Pengaruh Pertumbuhan Ekonomi, Pendapatan Asli Daerah, Dana Alokasi Umum, Dana Alokasi Khusus Terhadap Belanja Daerah Pada Kabupaten Dan Kota Di Provinsi Aceh. Jurnal Manajemen Indonesia (J-Mind), 2(1), 18-24. 
Salawali, A. W., Kindangen, P., \& Lapian, L., C. (2016). Flypaper Effect Pada Dana Alokasi Umum (DAU) Dan Pendapatan Asli Daerah (PAD) Serta Pengaruhnya Terhadap Belanja Daerah Kabupaten/Kota Di Sulawesi Tengah. Jurnal Pembangunan Ekonomi Dan Keuangan Daerah, 18(2).

Sasana, H. (2010). Flypaper Effect Pada Dana Alokasi Umum, Dana Bagi Hasil, Dan Pendapatan Asli Daerah Terhadap Belanja Daerah Pada Provinsi Di Indonesia. Eko-Regional, 5(2).

Sasana, H. (2011). Analisis Determinan Belanja Daerah Di Kabupaten/Kota Provinsi jawa Barat Dalam Era Otonomi dan desentralisasi fiskal. Jurnal bisnis dan ekonomi (Jbe) 18(1), 46-58. Setyorini, D. (2013). Pengaruh Dana Alokasi Umum, Pendapatan Asli Daerah Dan Pertumbuhan Ekonomi Terhadap Belanja Pemerintah Daerah Kabupaten Klaten Tahun 20022010. Doctoral Dissertation, Universitas Muhammadiyah Surakarta.

Shiddieqy, H. A., \& Afriana, R. A. (2016). Flypaper Effect Pada Dana Alokasi Umum (Dau) Dan Pendapatan Asli Daerah (Pad) Terhadap Belanja Daerah Pada Kota Dan Kabupaten Di Pulau Kalimantan. Dinamika Ekonomi-Jurnal Ekonomi Dan Bisnis, 6(2).

Sriwahyuni. (2010). Pengaruh pendapatan asli Daerah Dan Dana Alokasi umum terhadap belanja Daerah Di Indonesia (Studi kasus seluruh provinsi Di Indonesia). Tesis, Magister Akuntansi UMI, Makasar.

Sukartono. (2010). Pengaruh Pendapatan Asli Daerah Dan Dana Perimbangan Terhadap Belanja Daerah Serta Analisis Flypaper Effect Kabupaten/Kota Di Jawa Tengah Tahun 2006-2008. Telaah Manajemen.

Susilo, G. T. B., \& Adi, P. H. (2007). Analisis Kinerja Keuangan Anggaran Pendapatan Dan Belanja Daerah Sebelum Dan Sesudah Otonomi Daerah (Studi Empiris Di Propinsi Jawa Tengah). Konferensi Penelitian Akuntansi Dan Keuangan Sektor Publik Pertama. Surabaya.

Tuasikal, A. (2008). Pengaruh DAU, DAK, PAD, Dan PDBR Terhadap Belanja Modal Pemerintah Daerah Kabupaten/Kota Di Indonesia. Jurnal Telaah Danrisetakuntansi, 1(2), $142-155$.

Yulina, B. (2017). Fenomena Flypaper Effect Pada Dana Perimbangan Dan Pendapatan Asli Daerah Pemerintah Kabupaten/Kota DiSumatera Selatan. Jurnal Riset Terapan Akuntansi Polsri, 1(2).

Yustika, A. E. (2008). Desentralisasi Ekonomi Di Indonesia. Kajian Teoritis Dan Realitas Empiris. Malang. 